\title{
A study to measure the impact of customer perception, quality, environment concern and satisfaction on green customer loyalty
}

\author{
Hamid Reza Saeednia $^{a}$ and Saeeid Khodaei Valahzaghard ${ }^{b^{*}}$
}

${ }^{a}$ Assist. Prof. \& Faculty Member, Department of Commercial Management, School of Management, Tehran North Branch, Islamic Azad University (IAU), Tehran, Iran

${ }^{b}$ M.Sc. Student, Department of Commercial Management, School of Management, Tehran North Branch, Islamic Azad University (IAU), Tehran, Iran

\section{A R T I C LE I N F O A B T R A C T}

Article history:

Received July 16, 2012

Received in Revised form

August, 27, 2012

Accepted 20 September 2012

Available online

September 242012

Keywords:

Sequential equation modeling

Green products

Perception quality

Perception image

\begin{abstract}
Green product management plays an important role in today's economy and people are increasing becoming more interested in green products. In this paper, we present an empirical study to measure the impact of customer perception, quality, environment concern and satisfaction on green customer loyalty. The study proposes two hypotheses, where the first hypothesis studies whether the quality of green product has direct impact on customer satisfaction and the second hypothesis examines whether quality of green product has direct impact on customer loyalty. The population of this paper includes all people who use paperbased drinking glass, napkin and packaging products and live in city of Tehran, Iran. Since not all people are involved in all parts of the city in such product, we have decided to select only those who are involved in using these kinds of products including hospitals, universities, etc. The sampling technique has distributed 300 questionnaires and gathered 283 good quality ones for analysis. The questionnaire consists of 19 questions in five different perspectives. The proposed study uses sequential equation modeling and the results have confirmed both hypotheses.
\end{abstract}

2012 Growing Science Ltd. All rights reserved.

\section{Introduction}

Green management marketing is a growing concept, which includes various marketing based activities to improve environment (Menon \& Menon, 1997; Kotler \& Armstrong, 1999). Demand for ecological products and continuous business activities have increased people's awareness and, consequently, many governmental agencies have decided to set more restricted rules and regulations to reduce the burden of green gas effect (Mendleson \& Polonsky, 1995; Gurau \& Ranchhod, 2005). Green marketing management is new concept, which tries to meet people's requirements with minimum damage on the environment (Polonsky et al., 2001; Schellhase et al., 2000).

\footnotetext{
* Corresponding author. Tel: +98-912-3443139

E-mail addresses: mohamadkhodaei@yahoo.com (S. Khodaei Valahzaghard) 
Today, environmental issues are important factors among people, and people do their best reduce possible damages on the environment as much as they can (Albayrak et al., 2011). Customer loyalty is one of the most important aspects of marketing planning since customer retention is more important than customer absorption (Behara et al., 2002). Customer loyalty is a long term commitment for repurchasing products and services (Martensen et al., 2007). Customer loyalty is considered as a sustainable source of income and, at the same time, loyal customer are the best people for marketing products and services (Andreassen \& Lindestad, 1998).

Customer loyalty happens when customers find what they need from their suppliers and in some cases; this could help organizations on monopolizing the market (Bloemer et al., 1998). Environmental concerns on global warming have created tremendous efforts to reduce the impact of green gas effects. As a result, many firms and business strategies have adopted rules and regulations for better complying green product management (Moisander, 2008). A good knowledge on green products helps reduce human beings' damages on environment (Nguyen \& Leblanc, 1998; Lee, 2008; Govian, 2004). Therefore, people's purchasing intention will change and becomes the function of product characteristics (Smith \& Paladino, 2010). Theory of planned behavior (TPB) is a method for predicting consumers' behavior on green product (Bamberg, 2003).

Abdul-Muhmin (2002), for instance, investigated the effects of suppliers' marketing program variables on industrial buyers' relationship satisfaction and commitment. Kim and Chung (2011) in other study studied consumer purchase intention for organic personal care products and concluded that many customers care about product characteristics. Dembkowski (1998) considered the environmental value-attitude system model by investigating the divergence between stated environmental consciousness and overt consumer behavior. According to Subhani et al. (2012), many customers even prevent using products, which are not environment friendly.

Bamberg and Möser (2007) performed an investigation and a meta-analysis to find mean correlations between psycho-social variables and pro-environmental behavior. They also implemented the matrix of pooled correlations for a structural equation modeling (SEM) test. In their survey, they decided to find relationship between eight determinants of pro-environmental behavior of Meta-analytic SEM (MASEM). The results affirmed that pro-environmental behavioral intention could act as mediator for the effect of all other psycho-social variables on pro-environmental behavior. Their findings also confirmed that besides attitude and behavioral control personal moral norm was a predictor of proenvironmental behavioral intention. The MASEM also showed that problem awareness played an essential role but indirect determinant of pro-environmental intention and its effect appeared to be mediated by moral.

Aydin et al. (2005) in another investigation studied customer loyalty and the effect of switching costs as a moderator variable for a case in the Turkish mobile phone market. Behara et al. (2002) discussed that proving green products is one of the most important factors for building customer loyalty. Chang and Fong (2010) investigated the relationship between green product quality, green corporate image, green customer satisfaction, and green customer loyalty. Chen (2008) studied the driver of green innovation and green image -green Core competence. Chumpitaz and Paparoidamis (2004) in another survey investigated the relationship between service quality and marketing performance in businessto-business markets by exploring the mediating role of client satisfaction. Dembkowski (1998) in another study examined the environmental value-attitude system model to understand the divergence between stated environmental consciousness and overt consumer behavior. Eskildsen et al. (2004) studied the drivers of customer satisfaction and loyalty. Hellier et al. (2003) studied customer repurchase intention using a general structural equation model. Sinnappan and Abd Rahman (2011) studied the factors, which impact green purchasing behaviors of Malaysian consumers and observes when the factors influencing green purchasing behavior vary by demographic profile. Respondents in this investigation were consumers from different age groups, education level, ethnic group, etc. The 
results demonstrated that the best predictor for green purchasing behavior was environmental attitude followed by perceived environmental responsibility; environmental concern, perceived seriousness of environmental problems, perceived effectiveness of environmental behavior and government's role.

\section{The proposed study}

The proposed study of this paper considers the following two hypotheses,

1. The quality of green product has direct impact on customer satisfaction.

2. The quality of green product has direct impact on customer loyalty.

The proposed study of this paper tries to find green consumer pattern and to find major drivers in an attempt to take necessary actions for improving green product technology. The population of this paper includes all people who use paper-based drinking glass, napkin and packaging products and live in city of Tehran, Iran. Since not all those who live in this city are involved in using these kinds of products, we have decided to select those who are involved in using these kinds of products including hospitals, universities, etc. The sampling technique has distributed 300 questionnaires and gathered 283 good quality ones for analysis. The questionnaire consists of 19 questions in five different perspectives. The study gathers the ideas of Chang and Fong (2010), Lee (2008) and Tan (2011). The survey was performed in three stages. In the first stage, experts reviewed all questions and most part of ambiguity was deleted. In the second stage, the questionnaire was validated using a sample of 30 people and final questionnaire was prepared for the final stage. The study used Connergent validity, factor loading and Discriminant Validity (Average Variance Extracted, (AVE)) to verify the final questionnaire. All three coefficients were well above $0.5(>0.4)$ and t student values were well above 1.96 and the reliability of the questionnaire was verified. We have also used Cronbach's alpha, Dillon-Goldstein's rho and Composite Reliability tests for verification of the questionnaire and they were all within the acceptable levels.

\section{Table 1}

The results of statistical tests

\begin{tabular}{|c|c|c|c|c|c|c|c|c|c|}
\hline & \multicolumn{9}{|c|}{ Cross-loadings } \\
\hline Q. & Expected & Observed & GPQ & GCI & GCS & GCL & EC & $\begin{array}{l}\text { Factor } \\
\text { loading }\end{array}$ & $\begin{array}{l}\text { Critical } \\
\text { value }\end{array}$ \\
\hline GPQ1 & 1 & .62 & 0.804 & 0.516 & 0.535 & 0.487 & 0.278 & 0.804 & 26.288 \\
\hline GPQ2 & 0.8 & .62 & 0.806 & 0.499 & 0.399 & 0.431 & 0.252 & 0.806 & 26.473 \\
\hline GPQ3 & 1 & .62 & 0.639 & 0.368 & 0.296 & 0.302 & 0.241 & 0.639 & 11.652 \\
\hline GPQ4 & 1 & .62 & 0.774 & 0.559 & 0.396 & 0.491 & 0.234 & 0.774 & 26.116 \\
\hline GCI1 & 0.8 & .62 & 0.584 & 0.745 & 0.473 & 0.502 & 0.316 & 0.745 & 20.702 \\
\hline GCI2 & 1 & .62 & 0.541 & 0.816 & 0.379 & 0.454 & 0.213 & 0.816 & 25.287 \\
\hline GCI3 & 0.8 & .62 & 0.349 & 0.722 & 0.351 & 0.344 & 0.211 & 0.722 & 17.826 \\
\hline GCI4 & 1 & .62 & 0.410 & 0.674 & 0.546 & 0.441 & 0.283 & 0.674 & 13.947 \\
\hline GCS1 & 1 & .62 & 0.440 & 0.516 & 0.845 & 0.681 & 0.385 & 0.845 & 35.877 \\
\hline GCS2 & 0.8 & .62 & 0.398 & 0.494 & 0.876 & 0.643 & 0.316 & 0.876 & 48.075 \\
\hline GCS3 & 0.8 & .62 & 0.446 & 0.449 & 0.816 & 0.595 & 0.312 & 0.816 & 26.708 \\
\hline GCS4 & 1 & .62 & 0.504 & 0.490 & 0.718 & 0.506 & 0.343 & 0.718 & 16.539 \\
\hline GCL1 & 1 & .62 & 0.529 & 0.518 & 0.708 & 0.895 & 0.383 & 0.895 & 58.864 \\
\hline GCL2 & 1 & .62 & 0.540 & 0.562 & 0.640 & 0.860 & 0.420 & 0.860 & 42.332 \\
\hline GCL3 & 1 & .62 & 0.397 & 0.445 & 0.549 & 0.795 & 0.318 & 0.795 & 21.996 \\
\hline EC1 & 0.8 & .62 & 0.246 & 0.304 & 0.384 & 0.410 & 0.824 & 0.824 & 37.567 \\
\hline EC2 & 1 & .62 & 0.298 & 0.308 & 0.346 & 0.356 & 0.886 & 0.886 & 46.796 \\
\hline EC3 & 1 & .62 & 0.197 & 0.251 & 0.322 & 0.342 & 0.832 & 0.832 & 30.263 \\
\hline EC4 & 1 & .62 & 0.352 & 0.314 & 0.358 & 0.384 & 0.826 & 0.826 & 27.341 \\
\hline & & & 0.575 & 0.549 & 0.665 & 0.724 & 0.710 & & \\
\hline
\end{tabular}

There are five green perspectives measured in this questionnaire including green product quality (GPQ), green company image (GCI), green company satisfaction (GCS), green company loyalty 
(GCL) and environment concerns (EC). Table 1 shows details of the results, where all factors are presented factors with high ratios of eigenvalues are given in Table 1 . Table 2 shows details of all test used for the proposed study in two stages of initial and final stages. As we can observe from the results of Table 2, all Eighenvalues are located within acceptable levels.

Table 2

Validation of the questionnaire based different criteria

\begin{tabular}{lrrrrrr}
\hline & \multicolumn{2}{l}{ Initial } & \multicolumn{2}{l}{ Final } \\
\hline & \multicolumn{2}{l}{$\begin{array}{l}\text { Cronbach } \\
\text { alpha }\end{array}$} & \multicolumn{2}{l}{$\begin{array}{l}\text { Cronbach } \\
\text { alpha }\end{array}$} & $\begin{array}{l}\text { D.G. rho } \\
\text { (PCA) }\end{array}$ & $\begin{array}{r}\text { Eigenvalues } \\
\text { Composite } \\
\text { Reliability }\end{array}$ \\
\hline Green product quality (GPQ) & 4 & 0.735 & 0.756 & 0.847 & 0.844 & 1.449 \\
Green company image (GCI) & 4 & 0.794 & 0.728 & 0.833 & 0.828 & 1.871 \\
Green company satisfaction (GCS) & 4 & 0.773 & 0.831 & 0.888 & 0.887 & 1.811 \\
Green company loyalty (GCL) & 3 & 0.722 & 0.808 & 0.887 & 0.887 & 1.863 \\
Environment concerns (EC) & 4 & 0.847 & 0.851 & 0.902 & 0.900 & 1.264 \\
\hline
\end{tabular}

\section{The results}

The first measure we used was the mean of the numbers for all variables and they were varied between 3.480 and 4.459, which are highly meaningful. Standard deviation of all measures were from 0.610 to 0.990 and they are all less than 1 , which are, again, highly reliable. Skewness of all variables are negative, which means they the deviated data are located on the left side of the numbers and they are mostly follow normal distribution. Table 3 shows details of the changes for all components.

Table 3

The changes of different variables

\begin{tabular}{|c|c|c|c|c|c|c|c|c|c|c|c|c|c|c|c|c|c|c|c|}
\hline GPQ1 & 1.00 & & & & & & & & & & & & & & & & & & \\
\hline GPQ2 & 0.53 & 1.00 & & & & & & & & & & & & & & & & & \\
\hline GPQ3 & 0.38 & 0.47 & 1.00 & & & & & & & & & & & & & & & & \\
\hline GPQ4 & 0.47 & 0.43 & 0.35 & 1.00 & & & & & & & & & & & & & & & \\
\hline GCI1 & 0.43 & 0.46 & 0.35 & 0.51 & 1.00 & & & & & & & & & & & & & & \\
\hline GCI2 & 0.42 & 0.42 & 0.30 & 0.48 & 0.52 & 1.00 & & & & & & & & & & & & & \\
\hline GCI3 & 0.27 & 0.28 & 0.21 & 0.29 & 0.38 & 0.50 & 1.00 & & & & & & & & & & & & \\
\hline GCI4 & 0.37 & 0.29 & 0.22 & 0.34 & 0.24 & 0.36 & 0.40 & 1.00 & & & & & & & & & & & \\
\hline GCS1 & 0.46 & 0.33 & 0.18 & 0.32 & 0.42 & 0.29 & 0.32 & 0.49 & 1.00 & & & & & & & & & & \\
\hline GCS2 & 0.42 & 0.28 & 0.21 & 0.28 & 0.37 & 0.30 & 0.31 & 0.48 & 0.74 & 1.00 & & & & & & & & & \\
\hline GCS3 & 0.41 & 0.34 & 0.25 & 0.34 & 0.39 & 0.33 & 0.24 & 0.35 & 0.54 & 0.62 & 1.00 & & & & & & & & \\
\hline GCS4 & 0.46 & 0.36 & 0.35 & 0.36 & 0.36 & 0.33 & 0.27 & 0.47 & 0.42 & 0.47 & 0.51 & 1.00 & & & & & & & \\
\hline GCL1 & 0.47 & 0.37 & 0.29 & 0.45 & 0.40 & 0.38 & 0.34 & 0.41 & 0.65 & 0.62 & 0.55 & 0.47 & 1.00 & & & & & & \\
\hline GCL2 & 0.45 & 0.40 & 0.27 & 0.48 & 0.47 & 0.45 & 0.30 & 0.41 & 0.54 & 0.53 & 0.54 & 0.49 & 0.68 & 1.00 & & & & & \\
\hline GCL3 & 0.32 & 0.34 & 0.20 & 0.32 & 0.41 & 0.34 & 0.23 & 0.31 & 0.55 & 0.49 & 0.42 & 0.32 & 0.56 & 0.51 & 1.00 & & & & \\
\hline EC1 & 0.19 & 0.20 & 0.21 & 0.13 & 0.28 & 0.17 & 0.23 & 0.21 & 0.28 & 0.27 & 0.29 & 0.25 & 0.29 & 0.38 & 0.32 & 1.00 & & & \\
\hline EC2 & 0.20 & 0.22 & 0.25 & 0.23 & 0.31 & 0.21 & 0.14 & 0.18 & 0.29 & 0.25 & 0.22 & 0.22 & 0.29 & 0.24 & 0.31 & 0.62 & 1.00 & & \\
\hline EC3 & 0.12 & 0.13 & 0.09 & 0.19 & 0.23 & 0.16 & 0.15 & 0.15 & 0.23 & 0.20 & 0.25 & 0.22 & 0.28 & 0.34 & 0.17 & 0.57 & 0.66 & 1.00 & \\
\hline EC4 & 0.26 & 0.32 & 0.25 & 0.24 & 0.28 & 0.16 & 0.20 & 0.25 & 0.32 & 0.17 & 0.26 & 0.25 & 0.29 & 0.35 & 0.26 & 0.58 & 0.60 & 0.52 & 1.00 \\
\hline Mean & 4.233 & 4.039 & 4.322 & 4.113 & 3.841 & 3.481 & 3.509 & 3.894 & 3.905 & 3.788 & 4.053 & 4.124 & 3.710 & 3.661 & 3.636 & 4.360 & 4.389 & 4.307 & $\begin{array}{r}4.459 \\
\end{array}$ \\
\hline St.D & 0.759 & 0.826 & 0.724 & 0.839 & 0.899 & 0.990 & 0.885 & 0.877 & 0.830 & 0.824 & 0.834 & 0.814 & 0.938 & 0.890 & 0.956 & 0.611 & 0.727 & 0.705 & 0.653 \\
\hline Variance & 0.577 & 0.683 & 0.524 & 0.703 & 0.808 & 0.981 & 0.783 & 0.769 & 0.689 & 0.678 & 0.696 & 0.662 & 0.880 & 0.792 & 0.913 & 0.373 & 0.529 & 0.497 & 0.427 \\
\hline Skewness & -.908 & -.490 & -1.195 & -.870 & -.330 & -.243 & -.228 & -.777 & -.793 & -.241 & -.728 & -.947 & -.481 & -.373 & -.492 & -.486 & -1.193 & -.698 & -.887 \\
\hline Kurtosis & .759 & $\begin{array}{l}-.428 \\
\end{array}$ & 2.584 & .391 & -.560 & -.507 & .150 & .713 & 1.128 & -.104 & .311 & 1.171 & .071 & .004 & -.085 & -.120 & 1.757 & -.026 & .039 \\
\hline
\end{tabular}

We have also used structural equation modeling (SEM) to consider three important effects: first, we investigate the quality perception from green product, perception image from green product producers and their green customers' concern on customer satisfaction and loyalty. Second, the impact of green consumers' satisfaction on green consumers' loyalty is investigated. Finally, environment concern on perception quality from green product and perception image from green producer is considered. The results of our survey indicate that all t-student values from the implementation of LISREL software package have been statistically meaningful. Fitness criteria calculated through the sum of least square technique have indicated that external and internal models maintain 0.998 and 0.928 , respectively. In addition, absolute and relative criteria were 0.570 and 0.926 , which are statistically meaningful.

Based on the results of our SEM model, approximately, 0.11 of the changes from perception quality from green product can be estimated from environmental concern and the effect was 0.328, which was meaningful with the confidence value of $0.99 \%$. In addition, approximately, 0.12 of the perception image of green companies can be estimated from environmental customers' concerns. Finally, 0.435 of the green customers' satisfaction can be estimated from three mentioned variables, 
where .188\% is associated with perception quality, $0.156 \%$ is related to perception image and $0.091 \%$ is devoted to environmental concerns. The impact of four variables namely perception quality from green product, perception image from green product, environmental concern and green customers' satisfaction on loyalty towards green products are meaningful when the level of significance is one percent. In addition, $62.1 \%$ of green customer loyalty can be estimated based on these four variables where $8.5 \%$ is dedicated to perception quality from green product, $9.0 \%$ is devoted to perception image, $5.2 \%$ is associated with environmental concern and $39.5 \%$ is associated with green customer satisfaction.

The indirect impact of environmental concern on green customer satisfaction is 0.204 and total impact is 0.423 while the indirect impact on customer loyalty towards green products is calculated to be 0.324 and total impact is calculated as 0.443 . The indirect impact of perception of quality perception on customer loyalty towards green product was 0.151 with total impact of 0.299 . The indirect impact of perception image of green products on customer loyalty towards green products is 0.166 with the total impact of 0.316 . These results show that environmental concern is the major driver and plays an important role on customer satisfaction on green products and customer loyalty.

\section{Table 4}

The results of SEM implementation

\begin{tabular}{|c|c|c|c|c|c|c|c|}
\hline & & & & & \multicolumn{3}{|c|}{ Coefficient of determination } \\
\hline Affecting variable & Interact variable & Variable & Standard error & $\begin{array}{l}\text { Critical } \\
\text { ratio }\end{array}$ & Specific & Total & Critical ratio \\
\hline $\begin{array}{l}\text { environmental customer } \\
\text { concern }\end{array}$ & Quality of green product & 0.328 & 0.057 & 5.802 & 0.108 & 0.108 & 2.859 \\
\hline $\begin{array}{l}\text { environmental customer } \\
\text { concern }\end{array}$ & $\begin{array}{l}\text { Perception image of } \\
\text { green product }\end{array}$ & 0.350 & 0.057 & 6.128 & 0.122 & 0.122 & 3.080 \\
\hline $\begin{array}{l}\text { environmental customer } \\
\text { concern }\end{array}$ & $\begin{array}{l}\text { Green product customer } \\
\text { satisfaction }\end{array}$ & 0.219 & 0.024 & 9.155 & 0.091 & & \\
\hline Quality of green product & $\begin{array}{l}\text { Green product customer } \\
\text { satisfaction }\end{array}$ & 0.287 & 0.021 & 13.708 & 0.156 & 0.435 & 10.640 \\
\hline Perception image & $\begin{array}{l}\text { Green product customer } \\
\text { satisfaction }\end{array}$ & 0.314 & 0.018 & 17.425 & 0.188 & & \\
\hline $\begin{array}{l}\text { Environmental customer } \\
\text { concerns }\end{array}$ & $\begin{array}{l}\text { Green product customer } \\
\text { loyalty }\end{array}$ & 0.119 & 0.060 & 1.971 & 0.052 & & \\
\hline Quality of green product & $\begin{array}{l}\text { Green product customer } \\
\text { loyalty }\end{array}$ & 0.147 & 0.053 & 2.771 & 0.085 & 0.621 & 17.946 \\
\hline $\begin{array}{l}\text { Quality perception of } \\
\text { green product }\end{array}$ & $\begin{array}{l}\text { Green product customer } \\
\text { loyalty }\end{array}$ & 0.150 & 0.047 & 3.178 & 0.090 & & \\
\hline $\begin{array}{l}\text { Green product customer } \\
\text { satisfaction }\end{array}$ & $\begin{array}{l}\text { Green product customer } \\
\text { loyalty }\end{array}$ & 0.528 & 0.044 & 11.961 & 0.395 & & \\
\hline
\end{tabular}

Table 5 demonstrates the results of the impact of direct and indirect effects on internal as well as external variables.

\section{Table 5}

The impacts of direct and indirect effects on internal and external components

\begin{tabular}{lrrrrrrrrr}
\hline & \multicolumn{2}{c}{ Environmental concerns } & \multicolumn{2}{c}{ Customer's quality perception } & \multicolumn{3}{c}{ Perception image from green products } \\
& Direct & Indirect & Total & Direct & Indirect & Total & Direct & Indirect & Total \\
\hline Customer satisfaction & 0.219 & 0.204 & 0.423 & 0.287 & - & 0.287 & 0.314 & - & 0.314 \\
Customer loyalty & 0.119 & 0.324 & 0.443 & 0.147 & 0.151 & 0.299 & 0.150 & 0.166 & 0.316 \\
\hline
\end{tabular}

Fig. 1 shows details of the relationships of different variables where G.P.QUA represents green product quality perception, E.CON represents environmental concern, G.C.IMA denotes green consume perception image, G.C.SAT indicates green consumer satisfaction and finally G.C.LOY indicates green consumer loyalty. 


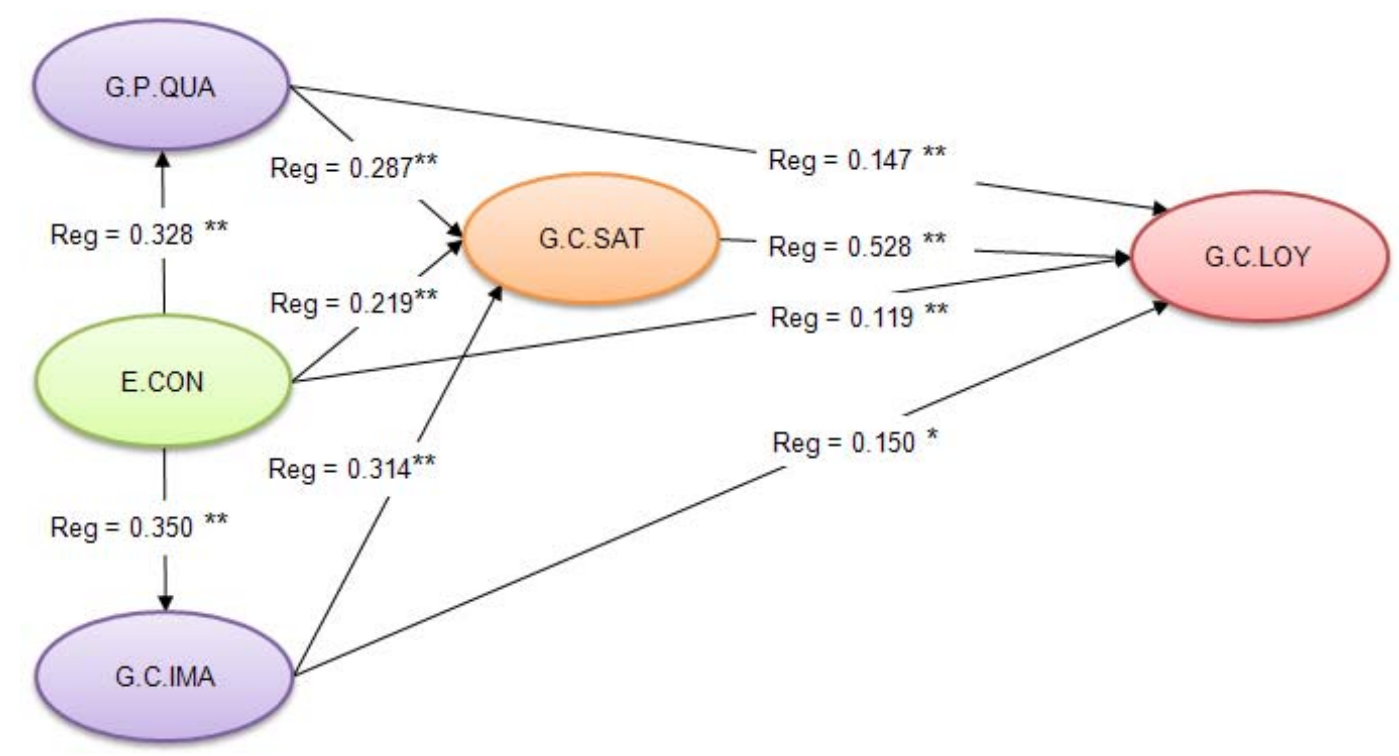

Fig. 1. The relationship among different variables $(* *$ Significance level $=1 \%$, *Significance level $=5 \%)$

\section{Conclusion}

In this paper, we have presented an empirical study to measure the relationship between The proposed study of this paper tries to find green consumer pattern and to find major drivers in an attempt to take necessary actions for improving green product technology. The population of this paper includes all people who use paper-based drinking glass, napkin and packaging products and live in city of Tehran, Iran. Based on the results of our SEM model, approximately, 0.11 of the changes from perception quality from green product can be estimated from environmental concern and the effect was 0.328 , which was meaningful with the confidence value of $0.99 \%$. In addition, approximately, 0.12 of the perception image of green companies can be estimated from environmental customers' concerns. Finally, 0.435 of the green customers' satisfaction can be estimated from three mentioned variables, where .188\% is associated with perception quality, $0.156 \%$ is related to perception image and $0.091 \%$ is devoted to environmental concerns.

The impact of four variables namely perception quality from green product, perception image from green product, environmental concern and green customers' satisfaction on loyalty towards green products are meaningful when the level of significance is one percent. In addition, $62.1 \%$ of green customer loyalty can be estimated based on these four variables where $8.5 \%$ is dedicated to perception quality from green product, $9.0 \%$ is devoted to perception image, $5.2 \%$ is associated with environmental concern and $39.5 \%$ is associated with green customer satisfaction.

The indirect impact of environmental concern on green customer satisfaction is 0.204 and total impact is 0.423 while the indirect impact on customer loyalty towards green products is calculated to be 0.324 and total impact is calculated as 0.443 . The indirect impact of perception of quality perception on customer loyalty towards green product was 0.151 with total impact of 0.299 . The indirect impact of perception image of green products on customer loyalty towards green products is 0.166 with the total impact of 0.316 . These results show that environmental concern is the major driver and plays an important role on customer satisfaction on green products and customer loyalty. 


\section{Acknowledgment}

The authors would like to thank the anonymous referees for constructive comments on earlier version of this paper.

\section{References}

Abdul-Muhmin, A.G., (2002), Effects of suppliers' marketing program variables on industrial buyers' relationship satisfaction and commitment. Journal of Business Industrial Marketing, 17(7), 637-649. Albayrak, T., Caber, M., Moutinho, L. \& Herstein, R. (2011). The influence of skepticism on green purchase behavior. International Journal of Business \& Social Science, 2(13), 189-197.

Andreassen, T.W., \& Lindestad, B. (1998). Customer loyalty and complex services. International Journal of Service Industry Management, 9(1), 7-23.

Aydin, S., Ozer, G., \& Arasil O. (2005). Customer loyalty and the effect of switching costs as a moderator variable: A case in the Turkish mobile phone market. Marketing Intelligence \& Planning, 23(1), 89-103.

Bamberg, S. (2003). How does environmental concern influence specific environmentally related behaviors? A new answer to an old question. Journal of Environmental Psychology, 23(1), 21-32.

Beerli, A. \& Martin, J.D. \& Quintana, A. (2004). A model of customer loyalty in the retail banking market. European Journal of Marketing, 38(1/2), 253 - 275.

Behara, R.S., Fontenot, G.F., \& Gresham, A.B. (2002). Customer process approach to building loyalty. Total Quality Management, 13(5), 603-611.

Bloemer, J., Ruyter, K., \& Peeters, P. (1998), Investing drivers of bank loyalty: The complex relationship between image, service quality, satisfaction. International Journal of Bank Marketing, 16(7), 276-286.

Chang, N.J., \& Fong, C.M. (2010). Green product quality, green corporate image, green customer satisfaction, and green customer loyalty. African Journal of Business Management, 4(13), 28362844.

Chen, Y.S. (2008). The driver of green innovation and green image -green Core competence. Journal of Business Ethics, 81(3), 531-543.

Chumpitaz, R., \& Paparoidamis, N.G. (2004). Service quality and marketing performance in business-to-business markets: exploring the mediating role of client satisfaction. Managing Service Quality, 14(2/3), 235-248

Dembkowski, S. (1998), The environmental value-attitude system model: understanding the divergence between stated environmental consciousness and overt consumer behavior. Ecomanagement and Auditing, 5(2), 62-74.

Eskildsen, J.K., Kristensen, K., Juhl, H.J., \& Østergaard, P. (2004). The drivers of customer satisfaction and loyalty. Total Quality Management Business Excellence, 15(5/6), 859-868.

Govina, N. A. (2004). Dictionary of Marketing Management Communication. SAGE Publications.

Gurau, C., \& Ranchhod, A. (2005). International green marketing a comparative study of British and Romanian firms. International Marketing Review, 22(5), 547-561.

Hellier, P.H, Geursen, G.M., Carr, R.A., \& Rickard, J.A. (2003). Customer repurchase intention - a general structural equation model. European Journal of Marketing, 37(11), 1762-1800.

Kim, H.Y., \& Chung, J.E. (2011). Consumer purchase intention for organic personal care products. Journal of Consumer Marketing, 28(1), 40-47.

Kotler, P., \& Armstrong, G. (1999). Principles of Marketing. Prentice-Hall International Inc.

Lee, K. (2008). Opportunities for green marketing: Young consumers. Marketing Intelligence \& Planning, 26, 573-586.

Martenson, R. (2007). Corporate brand image, satisfaction and store loyalty: a study of the store as a brand, store brands and manufacturer brands. International Journal of Retail Distribution Management, 35(7), 544-555. 
Mendleson, N., \& Polonsky, M.J. (1995). Using strategic alliances to develop credible green marketing. Journal of Consumer Marketing, 12, 4-18.

Menon, A., \& Menon, A. (1997). Enviropreneurial Marketing Strategy: The Emergence of Corporate Environmentalism as Market Strategy. Journal of Marketing, 61, 51-67.

Moisander, J. (2008). Motivational complexity of green consumerism. International Journal of Consumer Studies, 31(4), 404-409.

Nguyen, N., \& Leblanc, G. (1998). The mediating role of corporate image on customers' retention decisions: An investigation in financial services. International Journal of Bank Marketing, 16(2), 52-65.

Paladino, A. (2005). Understanding the green consumer: an empirical analysis. Journal of Customer Behaviour, 4(1), 69-102.

Polonsky, M.J., \& Rosenberger, P. J. (2001). Reevaluating Green Marketing: A Strategic Approach. Business Horizons.

Sinnappan, P., \& Abd Rahman, A. (2011). Antecedents of green purchasing behavior among Malaysian consumers. International Business Management, 5(3), 129-139.

Schellhase, R., Hardock, P., Ohlwein, M. (1999). Customer Satisfaction in Business-to-BusinessMarketing. The Journal of Business \& Industrial Marketing, 14(5/6), 416-432.

Smith, S., \& Paladino, A. (2010). Eating clean and green? Investigating consumer motivations towards the purchase of organic food. Australasian Marketing Journal, 18, 93-104.

Subhani, M.I., Hasan, S.A., Osman, A., \& Wazir Ali Rudhani, S. (2012). The Crux of Green Marketing: An Empirical Effusive Study. European Journal of Social Sciences (EJSS), 27(3), 425 435.

Tan, B.C. (2011). The Roles of Knowledge, Threat, and PCE on Green Purchase Behaviour. International Journal of Business and Management, 6(12), 14-27. 